\title{
EFFECTIVE CREATIVE INTERCULTURAL COMMUNICATION IN THE CONTEXT OF BUSINESS INTERACTION: THEORETICAL AND PRACTICAL ASPECTS
}

\author{
Justinas BRASLAUSKAS (D)* \\ Department of Creative Communication, Faculty of Creative Industries, \\ Vilnius Gediminas Technical University, Traku str. 1, LT-01141 Vilnius, Lithuania
}

Received 12 November 2019; accepted 11 March 2020

\begin{abstract}
Although various aspects of intercultural communication have been addressed in the works of various authors, there is still a lack of works that describe intercultural communication from the new viewpoint - in terms of effective intercultural business interaction, theoretical analysis of models of the classification of cultures, and combination of theoretical and practical insights in overcoming the obstacles of intercultural interaction. There is also a lack of works that highlight creativity as an integral part of cross-cultural business communication. In the belief of the author of the article, without a close synthesis of these aspects, it is impossible to understand in detail the meaning of effective intercultural business interaction. Purpose of the article - to analyse theoretical and practical aspects of effective cross-cultural business communication based on creativity. In the article, through the use of the models of the classification of cultures of various researchers from around the world (Richard R. Gesteland, Edward T. Hall, Richard D. Lewis, Geert Hofstede, Gert Jan Hofstede, Michael Minkov, Shalom H. Schwartz), the aspects of multiculturalism in the context of intercultural business interaction are highlighted. The work analyses creativity as an integral part of effective cross-cultural business communication. The publication also describes the barriers in the intercultural interaction and ways to overcome it. Research methods used in the work: systematic, comparative, logical analysis and synthesis of scientific literature.
\end{abstract}

Keywords: barriers to intercultural interaction, creativity, culture, intercultural communication, multiculturalism.

\section{Introduction}

Intercultural business interaction takes place in the medium of different cultures with their inherent features. Effective management of international constructive communication and negotiation management requires relying on adequate theoretical solutions and effective organisation of practical communication work. Therefore, it is necessary to analyse various aspects of internationalisation in intercultural communication.

*Corresponding author. E-mail: justinas.braslauskas@vgtu.lt 
Although various aspects of cross-cultural communication have been addressed in the work of various authors (Jančaitytė et al., 2009; Pruskus, 2004, 2010, 2013; Petkevičiūtė \& Budaite, 2005; Lustig \& Koester, 2006; Scollon et al., 2012), to date there is a lack of works that describe intercultural communication from the new viewpoint - in terms of effective intercultural business interaction, theoretical analysis of models of the classification of cultures, and combination of theoretical and practical insights in overcoming the barriers of intercultural interaction. There is also a lack of works that highlight creativity as an integral part of cross-cultural business communication. In the belief of the author of the article, without a close synthesis of these aspects, it is impossible to understand in detail the meaning of effective intercultural business interaction.

Problem. Underestimation of the importance of theoretical and practical harmony elements of intercultural interaction as well as the creativity aspect in constructive communication, without which it is impossible to develop an effective strategy for intercultural constructive communication.

Object of research - intercultural communication in the context of business interaction.

Purpose of the work - to analyse theoretical and practical aspects of effective cross-cultural business communication based on creativity.

Tasks of the work: 1) to analyse the aspects of multiculturalism in the context of intercultural business interaction through the models of the classification of cultures by various world scientists; 2) to analyse creativity as an integral part of effective cross-cultural business communication; 3 ) to describe obstacles to intercultural interaction and ways to overcome them. According to the author's belief, only with a proper understanding of the aspects listed in these tasks, it is possible to ensure the effective intercultural communication in the context of business interaction.

Methods of research - systematic, comparative, logical analysis and synthesis of scientific literature.

\section{Multiculturalism in the context of intercultural business interaction: theoretical aspects}

Communication of representatives of different cultures in the global world poses additional difficulties in evaluating the negotiating, business interaction skills of communicating subjects and in modelling strategic decisions. All of this implies the need to look for modeling approaches geared towards intercultural compatibility and a more efficient knowledge of the context of intercultural business interaction (Peleckis, 2016, p. 32).

Different authors have presented different classifications that indicate how the peculiarities of business interaction and negotiation of one culture depend on one or another cultural medium.

Cohen (1991, pp. 7-32) distinguishes between two paradigms of negotiation and business interaction: American and Oriental. In addition, negotiations, as well as various meetings and assemblies, form the basis for intercultural business interaction; therefore, we will place a greater emphasis on negotiations in this article. We will discuss these paradigms in more detail. 
The American culture of business interaction and negotiation is based on a verbal, explicit, low-context communication style. Low contextuality cultures are characterised by: 1) straight and expressive language; 2) limited attention to the use of non-verbal forms of interaction in communication; 3) clear and precise evaluation of all topics and issues covered; 4) treating tacitness as a lack of competence or lack or shortage of information; 5) open expression of dissatisfaction (Hall, 1983; Pruskus, 2012, p. 83). This paradigm is based on the principles of "I can do" and "give and take". In business interaction and negotiation, the representatives of the American paradigm, seeing the benefits of giving and taking, can do many processes that have not been fully included on the agenda of a business meeting, as well as agree on things other than what was initially intended. During negotiations, solutions are constantly sought here with the negotiating partner because it is believed that both sides must be motivated to solve problems just as much as they are interested in profit making (Pipirienè \& Maciukevičiené, 2011, p. 299). Time for the representatives of this paradigm always has real value, it is particularly true to the representatives of the United States (US) (Pruskus, 2004, pp. 187-188).

The Oriental paradigm of negotiation and business interaction is based on different negotiating characteristics. It is dominated by the internal, high-context communication style (Pipirienè \& Maciukevičienè, 2011, p. 299). High contextual cultures are characterised by: 1) unmanifested, concealed language, multiple pauses with multiple meanings; 2) focus on non-verbal communication and ability to "speak with the eyes"; 3) accurate, detailed conveyance of information, although basic words are sufficient for communication; 4) avoidance of open display of dissatisfaction under various conditions and results of interaction (Hall, 1983; Pruskus, 2012, p. 83). The oriental paradigm is characterised by the fact that business interaction, negotiation is taking place and decisions are made much more on the basis of the collective opinion rather than personal attitudes. Establishing and consolidating personal relationships during business interaction and negotiations is considered a very important aspect of communication. In this intercultural communication paradigm, great importance is attached to history, the course of the meeting, the atmosphere, the patience and the tolerance. Agreement can only be reached after good relations have been established and there is no rush to reach the end of the negotiations (Pipiriene \& Maciukevičienè, 2011, p. 299). This paradigm is represented by countries such as Japan, China, etc. (Pruskus, 2004. pp. 206-217).

Casse and Deol (1985) have distinguished between a broader classification of negotiation and business interaction cultures - three paradigms - Japanese, North American, and Latin American. The Japanese and North American paradigms are largely the equivalent of the Cohen's (1991) oriental and American paradigms. The Latin American negotiating and business interaction paradigm is characterised by the fact that the behaviour of the representatives of this paradigm is based on emotions that are clearly displayed and are of great significance. Power and its display are highly valued in this paradigm. The whole team is involved in the decision-making process, but the final decision is made not by a specific person, as in the American paradigm, but by the person with the greatest power. Also in the Latin American paradigm much attention is placed on the atmosphere, relationship and exceptionally dignity (Pipirienė \& Maciukevičienè, 2011, pp. 299-300). 
Gesteland (1997) distinguished the classification of intercultural interaction and negotiation types by the treatment of the main aspects of negotiation (subjectivity, formality, time and emotionality). It allows for a flexible look at the features of intercultural interaction and negotiating in terms of country and region, without only being attached to geographic distribution. The author analyses cultures in accordance with the following dimensions: 1) focus on business matters and interpersonal relationships; 2) formality and informality; 3) time and agenda orientation; 4) expressiveness and reservation.

We will discuss the above classification in more detail, as the latter, in the opinion of the author of this article, best illustrates the peculiarities of multiculturalism in intercultural business interaction.

Business orientation and interpersonal orientation. In introducing this dimension, Gesteland, in turn, distinguishes between the following types of cultures: 1) cultures focused on business affairs (Nordic and Germanic Europe, United Kingdom (UK), North America, Australia, New Zealand, South Africa); 2) cultures moderately focused on business affairs (Southern Europe, Eastern Europe, Mediterranean region, Hong Kong, Singapore); 3) cultures focused on mutual relations (Arab States, most of Africa, Latin America, most of Asia) (Gesteland, 1997, p. 18).

In the global markets, the overwhelming majority are business cultures focused on mutual relations. People in these cultures prefer to work with family members, friends, and well-known individuals or their groups, and find it uncomfortable to work with foreigners (Gesteland, 1997, p. 17). Such features are, for example, typical of Japan, which is often referred to as the "spider society" (Lewis, 2002, pp. 378-379). In order to establish a business contact with persons from the business culture focused on interpersonal relations, for example, Japanese, you need to be introduced by a third party - an intermediary (Gesteland, 1997, p. 21). This could be a businessman or a firm well-known to both parties. The services of this intermediary may be remunerated in terms of money or relevant services (Pruskus, 2004, p. 210).

Business orientation, on the contrary, is limited to a small part of the world where entrepreneurs build contacts rather easily with unknown partners without any prior preparation, interaction or relations (Gesteland, 1997, pp. 17, 19). The best example of a business-oriented culture is the US. It is easiest to deal with the US representatives in many respects because their business interaction philosophy is based on pragmatism and is simple (Lewis, 2002, p. 166).

Cultures oriented to business relations and mutual relationship also differ in the way they interact. Negotiators on the business-oriented side tend to prefer straightforward, open, simple language, while negotiators on the relationship side tend to prefer using the indirect, subtle, and sophisticated style. The latter prefer harmonious and smooth interrelations. They strive to preserve harmony by carefully controlling their language and actions so as not to offend others or place them in an uncomfortable situation (Gesteland, 1997, pp. 35-36). For example, the Japanese avoid the use of the word "no" in their negotiations as they believe this can lead to disharmony in the negotiations (Lewis, 2002, pp. 381, 383).

Formality and informality. There are formal and informal business cultures. Gesteland argues that formal cultures tend to be divided into hierarchies that reflect the position and 
authority of their members. Meanwhile, informal cultures more appreciated egalitarian societies with less differences in status and power (Gesteland, 1997, p. 45). A more detailed breakdown of the above cultures is also possible: 1) highly informal cultures (Australia, US); 2) completely informal cultures (Canada, New Zealand, Denmark, Norway); 3) formal cultures (majority of Europe, Mediterranean region, Arab countries, Latin America, most of Asia (Gesteland, 1997, p. 47).

Contrary perceived values can lead to conflicts and distrust at the negotiating table. For example, when negotiating with German businessmen, it is strongly recommended that they be called by surnames and make sure not to forget their titles. It is not advisable to make jokes during business meetings with Germans. German formalism is not limited to the negotiations: even in the workplaces, where they have been working together for many years, their address their colleagues by surnames (Lewis, 2002, pp. 197, 199, 201). Americans are quite a different; although they always feel at ease, they do not like the formal atmosphere when interacting with partners (Pruskus, 2003, p. 296).

Time and agenda orientation. Different cultures have different perceptions of time and agendas. The latter aspect hinders effective constructive communication. In societies that treat the time strictly, punctuality is a must, agendas are untouchable, and business meetings are rarely interrupted. Gesteland describes these cultures as monochronic in his model of business interaction between different cultures. Their opposition are polychronic societies that pay less attention to punctuality and less respect the terms. Polychronic cultures appreciate looser agendas or business meetings, which may include several "meetings within meetings". Gesteland subdivides these different cultures further: 1) highly monochromic cultures (Nordic and Germanic Europe, North America, Japan); 2) average monochromic cultures (Australia, New Zealand, Eastern Europe, Southern Europe, Hong Kong, Singapore, Taiwan, China, South Korea); 3) polychronic culture (Arab States, Africa, Latin America, South and Southeast Asia) (Gesteland, 1997, p. 57).

Different perceptions of time and agenda leads to conflicts. Rarely does anyone from the northern Europe or North America accept the polychronic use of time (Pruskus, 2004, pp. 120-121).

Expressiveness and reservation. There are expressive and reserved cultures. Gesteland gives the following sub-classification of such cultures: 1) highly expressive cultures: Mediterranean region, Southern Europe, Latin America; 2) medium expressive cultures: US and Canada, Australia and New Zealand, Eastern Europe South Asia; 3) reserved cultures: East and SouthEast Asia, Nordic and Germanic Europe (Gesteland, 1997, p. 68). Representatives of reserved culture do not like to talk much, they prefer listening. Listening is a necessary attribute of their interaction with others. Representatives of this culture are introverts, distrustful of excessive words and therefore skilled in interacting without words. This is assisted by the subtle expression of the body, which is fundamentally different from the exuberant handwaving of the Romance peoples and Africans (Pruskus, 2004, p. 110).

At the turn of the century Hall divided cultures into: 1) high and low context; 2) monochronic and polychronic (Hall, 1983; Nardon \& Steers, 2009, p. 5). The characteristics of low- and high-context cultures have been discussed when analysing the paradigms of negotiating and business communication: American and Oriental. The characteristics of mono- 
chronic and polychronic cultures have been discussed in the analysis of the classification of Gesteland's (1997) intercultural communication and negotiation types, in which this author incorporated some elements from the Hall's model of cultural classification. According to Hall, different cultures have different perceptions of space. There are cultures characterised by the need for a defined personal space between themselves and others (US, Japan). Contrary to these cultures are Latin American and Arabic countries with inherent community sense. Representatives of these cultures feel comfortable in a common space with others (Nardon \& Steers, 2009, p. 5).

Lewis (2002) divides the peoples' cultures into three groups in accordance with their focus to the outside world: 1) focus on achieving the target (representatives are highly organised planners (single plan)); 2) focus is on people (representatives are talkative, looking for interconnection (multi-plan)); 3) focuses on respect for people (representatives are reserved, introverted) (Lewis, 2002, pp. 42-56). The classification of mono-planar and multi-planar cultures here corresponds essentially to the aforementioned Hall's classification of monochronic and polychronic cultures.

Geert Hofstede (Hofstede et al., 2010, pp. 53-298) proposed a paradigm where he distinguished six cultural dimensions (problems that each culture faces and solves in its own way), by which individual cultures can be described and compared: 1) power distance; 2) avoidance of uncertainty; 3) individualism - collectivism; 4) masculinity - femininity; 5) longterm - short-term orientation; 6) satisfaction and constraint. These dimensions must be taken into account in pursuit for effective intercultural business and economic interaction, and for productive negotiation. It is obvious that only the better understanding of mentality of different cultures will enable us to apply our communication strategy with other cultures more effectively.

Power distance. This distance is associated with the desirability or unwantedness of inequality in society as well as the levels of dependence and interdependence. This dimension shows the extent to which employees recognise that those above them in their management hierarchy have power. In cultures with a higher power dimension, managers and subordinates regard each other as unequal. They do not feel uneasy as a result but rather accept as an inevitability that must be accepted. Here, power is centralised and subordinates are expected to follow instructions. In the cultures with lower power distance, managers and subordinates are treated more equitably and there are no strict boundaries between them (Peleckis, 2016, p. 37). As a contrast - cultures based on different power distance, we can identify China, Malaysia, Indonesia, Philippines, India, Arab countries, Mexico, Venezuela, Ecuador (very strong power distance) and Switzerland, Finland, Norway, Sweden, Ireland, New Zealand, Denmark, Austria, Israel (very weak power distance) (Hofstede et al., 2010, pp. 57-59).

Uncertainty avoidance dimension. The uncertainty avoidance dimension expresses ambiguity, lack of tolerance, and the need for formal rules. It shows the extent to which people in a society feel the threat of uncertain situations and try to avoid them. In the countries of the avoidance of high uncertainty, characterised with low uncertainty avoidance, different rules and procedures are emphasised less because they rather rely on common sense and generalization (Peleckis, 2016, p. 37). Societies with uncertainty try to cope with the help of technology, law and religion. In organisations these spheres response to the technology, 
rules and rituals (Pruskus, 2004, p. 76). High uncertainty avoidance indexes exist in countries such as Greece, Portugal, Belgium, Spain, France, Japan, Guatemala, Uruguay, Salvador, Peru, Argentina, Panama, Chile, Costa Rica, low uncertainty avoidance index is characterised by such countries as the US, UK, Ireland, Sweden, Denmark, Jamaica, India, Malaysia, Philippines, Hong Kong, Singapore (Hofstede et al., 2010, pp. 192-194).

The dimension of individualism - collectivism. The dimension of individualism - collectivism indicates the extent to which individual interests are given the priority in respect of interests (Peleckis, 2016, p. 37). Strong individualism is difficult for developed countries such as US, Canada, UK, Italy, Belgium, Denmark, Sweden, France, the Netherlands, Australia, New Zealand. Weak individualism and strong collectivism are found in countries such as China, Taiwan, Indonesia, Singapore, Thailand, South Korea, Pakistan, West Africa, Colombia, Venezuela, Salvador, Panama, Ecuador, Guatemala, Costa Rica, Peru (Hofstede et al., 2010, pp. 95-97).

The dimension of masculinity - femininity. In terms of this dimension, masculinity and femininity are understood here not in biological terms, but in the social sense. The IBM study found that almost everywhere, women see the social goals such as good relationships, respect to others and the physical environment, as more important, while men prefer the so-called ego goals such as career and money (Pruskus, 2004, p. 67). Thus, this dimension describes what members of the public place more emphasis on: perseverance and work goals (such as salaries and promotions) or care and personal goals (such as a friendly atmosphere, good relationships with management and other employees). For this reason, more feminine societies adapt better to gender differences than masculine societies (Peleckis, 2016, p. 37). Very weak masculinity or, in other words, very strong femininity is observed in countries such as Sweden, Norway, the Netherlands, Denmark, Finland, Portugal, Chile, Costa Rica, Thailand, very strong masculinity, or, in other words, very weak femininity, is prevalent in countries such as Japan, Austria, Italy, Switzerland, Ireland, UK, Germany, Venezuela, Mexico, Jamaica (Hofstede et al., 2010, pp. 141-143).

Long-term - short-term orientation dimension. This dimension is based on the teaching of the Chinese philosopher Confucius (Pruskus, 2004, p. 100). The dimension describes how quickly the members of the public expect the results. Long-term orientation provides for the promotion of traits focused towards rewards in the future, namely the endurance and cost effectiveness. Short-term orientation provides for the promotion of traits related with the past and present, namely, respect for traditions and fulfilment of social obligations (Peleckis, 2016, p. 37). Long-term orientation is typical for countries like China, Taiwan, Hong Kong, Japan, South Korea, short term - US, Canada, UK, Philippines, Pakistan, Nigeria, Zimbabwe (Hofstede et al., 2010, p. 240).

The dimension of satisfaction or restraint. Communities with a high level of satisfaction can be relatively free to enjoy life and have fun with it, while restrained societies suppress the personal fulfilment of personal needs and are governed by strict social norms (Peleckis, 2016, p. 37). The pole of satisfaction is represented by the North and South America, Western Europe, some African countries, restraint - Eastern Europe, Asia, ad Muslim countries (Gudonienè, 2013, p. 186). 
Schwartz identified seven dimensions in analysing differences in value between countries: 1) conservatism (or dependence); 2) hierarchy; 3) excellence; 4) emotional autonomy; 5) intellectual autonomy; 6) dedication to egalitarianism (equivalence); 7) harmony (2006, pp. 140-142). Schwartz's theory of cultural differences, which is based on research carried out in 54 countries, is also used in the research of values in the European Union countries. The results of this study by country show a significant correlation with the results obtained by Geert Hofstede (Gudonienè, 2013, p. 187).

The classification of world cultures classification in the works is addressed by other scientists, such as Steenkamp (2001), Tsang (2011), Heales, Cockcroft, and Raduescu (2004), Javidan (2004), Trompenaars and Hampden-Turner (2012), however, their work will not be analysed in more detail in this paper because, in the opinion of the author, the classifications of scholars discussed in this publication are sufficiently representative of cultural differences.

In accordance with the author, after analysing the classification models of the cultures of different scholars around the world, Gesteland's classification of cultures is probably the best in reflecting the cultural differences of the countries of the world and allows to relate it easily to the representation of these differences in the process of intercultural business interaction. It goes without saying that the classifications of cultures of other discussed scientists are no less significant and could be relied on in preparing developing effective international business interaction strategies.

\section{Creativity as an integral part of effective cross-cultural business communication}

Effective cross-cultural communication in the context of business communication must have elements of creativity. It is not sufficing for the participants of international business communication to be aware and understand the models of classification of different cultures of the world, and to rely solely on this knowledge to develop effective international business communication strategies. The "approach" itself to people of different cultures should be original, creative. Rakauskaite (2014, p. 337) distinguishes five conditions needed to unfold a creative approach: 1 ) the main prerequisite is the ability to surprise; 2) the ability to concentrate, to perceive oneself as the true one, able to create the centre of the world and at the same time to transcend one's personal boundaries, to blend in with others, to feel unity with the world; 3) personal, "I" experience; 4 ) the ability to accept conflict and stress rather than avoid them. The tension stemming from polarity is a prerequisite for human existence, necessary for the development of spiritual strength and creative imagination; 5) courage and faith allowing to trust one's experience and any new experience to emerge.

Creativity is a complex concept and has many definitions - the most common terms are used relate to a person, a product or a process. By interpreting creativity as a consequence of social and cultural processes, it is an approach that an individual can be creative only in a certain social context: "[...] we cannot explore creativity by isolating individuals and their work from the social and historical environment in which they operate" (Csikszentmihalyi, 1988, p. 325). We will not find creativity in the brain of an individual or embodied in artefacts - it arises from the interaction between an individual's thinking and a socio-cultural context. 
In the report 21st Century Skills, Education and Competitiveness, the role of creativity in organisations, including business organisations, was highlighted as the most important and creativity-related skills formulated - solving complex, interdisciplinary, open issues; creative and entrepreneurial thinking; innovative use of knowledge, information and opportunities (Partnership for 21st Century Skills, 2008). In order to survive, to be able to communicate effectively with each other internationally, organisations must offer solutions to the changing societal needs. The increasing pace of change increases the expectations of the creative skills of the workforce and employee careers are increasingly open and no longer confined to the improvement of one product or service.

Another important trend that supports the interesting creativity of organisations, in particular in the private sector, is the desire to be innovative - in order to remain competitive, organisations must not only adapt to change but manage those changes, applying innovative business practices, processes, including the process of efficient cross-cultural communication, products and services (Černevičiūtè \& Strazdas, 2014, p. 116).

It is important to understand the impact of the external environment - the macroenvironment - on creativity. The macro environment is the external environment outside the organisation - it can be the market, government policy, scientific and technological development, the broader political and social system, which can determine the work of the organisation.

The macroenvironment of creativity also includes national culture, defined as traditions, values, symbols, heroes and rituals that shape behaviour and support the right perception of the world (Adler, 2002). In some cultures, more emphasis is placed on individual creators, while in others, creativity is a collective action and occurs in groups. In some cultural environments, everyone can be creative, in others, it is an exceptional talent that only exceptional people possess. Cultures that focus on exceptional cases of creativity tend to highlight the individual characteristics of such exceptional people by diminishing their environmental impact (Černevičiūtė \& Strazdas, 2014, p. 117). It is believed that this trend is related to the dimensions of individualism-collectivism in culture (remember the paradigm proposed by Hofstede, Hofstede, and Minkov (2010), with its six cultural dimensions).

Effective cross-cultural business communication usually takes place in teams: this is especially true in the case of negotiations. Teamwork corresponds to the so-called "small-world network", one of the most effective forms of social organisation for creativity and tasks. Small worlds have been found to host a remarkable variety of systems, including friendships, collaborations of all kinds, corporate alliances, production teams in business (Černevičiūte \& Strazdas, 2014, p. 116).

Thus, only by understanding the importance of creativity, it is possible to effectively communicate with foreign partners in the context of business communication, to negotiate, and make innovative decisions. Rakauskaite (2014, p. 344) points out that creativity "is not an exclusive attribute of gifted people, but is achievable to every individual, it is an ability that we must continually cultivate". Practical aspects of creativity education are widely discussed in the works of Rakauskaitė (2014), Grakauskaitè-Karkockienè (2002), therefore, we will not analyse them in detail in this article. 


\section{Barriers to intercultural interaction and ways to overcome them: theoretical and practical insights}

Effective intercultural constructive communication is impossible if we do not perceive the barriers to intercultural interaction and do not know the ways of removing them.

In accordance with Gudykunst and Kim (1997), the success of communicating with strangers depends on how much we are doing to manage anxiety and uncertainty. These authors distinguish the concept of the upper and lower uncertainty threshold (Gudykunst \& Kim, 1997, p. 33). In accordance with them, effective communication requires our uncertainty to be between the highest and the lowest threshold of uncertainty, in other words, we cannot be completely sure that we understand. When our uncertainty is below the maximum threshold, we rely on the information available, on the basis of which we can predict and explain to the behaviour of other people or their messages. If our uncertainty is below the minimum threshold, we find that other people's behaviour is completely predictable, which makes us bored, lacking in interest and the motivation to communicate. However, the latter belief is not always correct and may lead to errors in the interpretation of the communication message (Gudoniené, 2013, pp. 66-67).

Anxiety and uncertainty in communicating with the representatives of other cultures can be reduced if we have a variety of intercultural communication competencies. Some authors (Jiaquan, 2009, p. 28) define intercultural competence as the ability to communicate with people from other cultural backgrounds, which encompasses three aspects: formation of cultural awareness (including a comprehensive understanding of one's own culture and attitudes towards other cultures); awareness of cultural knowledge; developing intercultural interaction skills and the ability to use them effectively in intercultural situations. Lazauskiene and Rimienè (2018, p. 46) mention the following aspects of intercultural communication competences: cultural awareness, intercultural sensitivity and intercultural adroitness. Petkevičiūte and Budaite (2005, p. 136) describe intercultural competence as the ability of an individual (or organisation) to work effectively in a diverse environment. The authors also note that the following elements of intercultural competence content are commonly identified: cultural awareness, cultural knowledge, cultural sensitivities or cultural attitudes, cultural skills.

There are three main areas where intercultural communication competence is important: communications, business and military.

In the field of communication, the intercultural communication competence covers areas such as: personality (important are human traits that influence intercultural human communication), communication skills (individuals must be competent in both verbal and nonverbal communication), psychological support (a competent person must be able to acclimatise to a new environment), cultural awareness (individuals must understand social customs, social system of other cultures etc.) (Petkevičiūtė \& Budaitè, 2005, p. 137).

Asta Radzevičienè states that an individual's intercultural competence in the field of business manifests itself in: 1) knowledge of business cultures as well as customs, traditions and negotiation strategies of other countries; 2) ability to analyse and adequately understand and respond to different cultural contexts; 3) knowledge of other countries' political and business philosophies and trends, ability to establish contact with business and political leaders 
representing different cultures; 4) ability to work effectively in multicultural teams or in multicultural environments; 5) knowledge of languages (2004, p. 63).

In the military field, the following aspects of intercultural interaction competence ensure the effectiveness of intercultural communication: 1) awareness; 2) trust; 3) interaction; 4) mutual understanding; 5) adaptability; 6) certainty; 7) initiative; 8) approval (Petkevičiūtè \& Budaite, 2005, pp. 136-137).

Jančaitytė, Valavičienè, Augutienè, and Prakapas (2009, p. 89) in their work present a model of S. A. Beebe, S. J. Beebe, and Ivy (2007) of effective interaction in overcoming differences, which can be defined as the development of cultural competence. In accordance with S. A. Beebe, S. J. Beebe and Ivy (2007), knowledge, motivation, and skills are required to acquire competence. Knowledge of others to overcome differences can be gained through two strategies: 1) seeking information on other cultures; 2) asking and listening for answers. Acquiring and maintaining motivation to adapt to others requires: 1) to be patient; 2) to endeavour to tolerate ambiguities and uncertainties; 3 ) to be attentive to the differences that exist. Key skills in communicating with people who are different: 1) to be focused on others; 2) to adapt interaction to others accordingly.

The excellent mastery of competencies cannot fully guarantee the absence of conflict situations that may arise in intercultural business interaction, especially in business meetings and negotiations. It is therefore necessary to know the different styles of conflict resolution in intercultural business interaction, negotiation and, where appropriate, to choose the right conflict resolution strategy.

Below is the description of five conflict resolution styles of international negotiations and business interaction in general (Miller, 2014, p. 202; Peleckis, 2015, p. 68): 1) competing style; 2) adaptive style; 3) avoidance style; 4) collaborative style; 5) compromise style.

Competing style. It is a style that has features of non-cooperation and categorisation. Participants pursue their goals at the expense of others. It is the model focused on the use of powers, which uses what it takes to win (Peleckis, 2015, p. 68). Within this style, usually one negotiating party wins, the other loses (Mažeikienè \& Peleckis, 2011, p. 205; Peleckis et al., 2016, p. 240).

Adaptive style. This style has the qualities of collaboration and non-categorization, in contrast to the competing style. Participants ignore their own problems, to meet the different interests of the participants, it is a self-sacrificing style (Peleckis, 2015, p. 68). Adaptation attitude is chosen in the negotiating when sacrificing something now in order to achieve future benefits, solve the problem faster (Peleckis et al., 2016, p. 243).

Avoidance style. This style has the properties of non-categorization and non-cooperation. Participants do not seek to solve their problems immediately, nor do they seek conflict. Avoidance occurs by delaying a problematic topic, waiting for a better moment, or avoiding a dangerous situation (Peleckis, 2015, p. 68). This style reflects the one wins - the other loses, or both lose negotiating strategy (Mažeikienè \& Peleckis, 2011, p. 206; Peleckis et al., 2016, p. 242).

Collaborative style. This style has both categorical and collaborative qualities, as opposed to avoidance. Collaborative style involves the aim of cooperating with another participant in finding solutions that fully satisfy the objectives of the two negotiating participants. This 
means that participants are deeply addressing the issues of negotiation, both in identifying the main problems and in finding the key alternatives to resolving issues that would satisfy the objectives of both participants (Peleckis, 2015, p. 68). This style expresses the both win negotiation strategy, with each party seeking an agreement that satisfies both of them (Peleckis et al., 2016, p. 243).

Compromise style. This style is an intermediate position between categorisation and collaboration. Its aim is to find mutually acceptable solutions to the problem that are mutually accepted and partially meet the participants' expectations. This style also has the properties of competitive and adaptive styles. Here, problems are tackled more actively than in the avoidance style, but not so thoroughly and completely than in the collaborative style (Peleckis, 2015, p. 68). The style expresses the both lose strategy (Mažeikiené \& Peleckis, 2011, p. 206; Peleckis et al., 2016, p. 241).

If these conflict resolution styles are more suited to the negotiation situation, then these practical tips for dealing with conflicts arising in intercultural business interaction are more universal, namely: 1) staying focused on the essentials and not polarising (good - bad, positive - negative); 2) maintaining the contact: not to break the relationship, to encourage dialogue, not to isolate from one another; 3 ) recognise the existence of other styles: each person has his or her own conflict resolution style, which also has good qualities; 4) choose the own conflict resolution style: most people use the same style in similar situations; it is necessary to recognise and name their own style; 5) be creative and expand the style repertoire: not to stick to one style but to evaluate which style would be most acceptable in the current situation; 6) recognising the importance of the context of conflict: understanding of the wider social, economic, cultural, political context, which is the background for many conflicts; 7) be prepared to forgive: it is especially useful in solving intercultural conflicts, as accusation leads to stress, physical problems and even the burnout syndrome (Jančaitytė et al., 2009, p. 96).

Not only the problem of anxiety and uncertainty, lack of competence in intercultural communication, lack of an appropriate strategy for resolving conflict arising in intercultural interaction or negotiation can become serious obstacles to intercultural business interaction. Our individual reactions, which can be hostile, can also be hostile. Hostile reactions include: 1) a sense of superiority; 2) ethnocentrism; 3) cultural relativism, the premise of universality; 4) stereotypes (Gudonienè, 2013, pp. 68-73).

A sense of superiority. Representatives of many cultures believe that their values and practices are better than those of the rest of the world (Gudoniene, 2013, p. 69).

Ethnocentrism. It is the evaluation of other cultures or societies based solely on the criteria of one's own culture or society. It is characterised by the tendency to evaluate the own group to which one belongs, better than others (Leončikas, 2004, p. 638). Sometimes ethnocentrism can be a cause of hostility to another culture. Ethnocentrism exists in all nations, and this is reflected in the drawing of maps: In the US published world maps, this country is most often positioned in the centre, in the British maps of the Western Europe is in the centre (Gudonienè, 2013, p. 70). It is very important for people to be focused on others for effective intercultural interaction. Being focused on others means considering the other person's thoughts, feelings, and needs while maintaining their integrity during communication. How does one become focused on others? Jančaitytè, Valavičienė, Augutienè, and Prakapas (2009, 
p. 90) identifies two stages to this becoming: 1) being socially good. It is a cognitive process of trying to understand what another person is thinking: taking into account the other person's values, thoughts and attitudes; 2) being empathetic. It is the process of trying to feel what another person is feeling.

Cultural relativism, the premise of universality. Cultural relativism can be described as follows: it is a theory of cultural anthropology based on tolerating the cultural standards of other nations. Cultural relativism interprets cultural characteristics as elements of a particular distinctive cultural system, the behavioural meanings of its subjects - in accordance with the characteristics of their culture, and criticises the biased interpretation of peoples and entire cultures solely based on the customs of the own national culture (Leonavičius, 2007, p. 231). Often, similarity is emphasised when they say: "maybe they dress, eat, build homes differently, but they are basically the same as us". However, this is a misguided and sometimes dangerous attitude. If we think we know how the other thinks based on our own perspective, this is called projected cognitive similarity. The assumption that we know what the other is thinking, may disrupt the communication process and even cause conflicts (Gudoniene, 2013, p. 71). When interacting with people from different cultures, it should be borne in mind that even if they agree on common goals, they can pursue them in different ways. However, a certain degree of cultural realism is inevitable if we are to understand better the behaviour of strangers.

Stereotypes. This is yet another expression of the reaction of prejudice in intercultural interaction. Stereotypes reduce the uncertainty in the communication process and increase our confidence in predicting the behaviour of strangers. But most often, based on stereotypes, we overestimate the commonalities of a group, underestimate individual differences, and do so automatically without thinking (Gudonienè, 2013, p. 74). Pruskus (2010, pp. 32-33) distinguishes the following social functions of stereotypes in accordance with their significance in intercultural communication: 1) function of the transfer of relatively reliable information; 2) orientation function; 3 ) function of positioning the attitude in relation to the alien culture.

Gudonienè (2013, p. 77) notes that even the theoretical analysis of intercultural communication, theories and studies of cultural differences themselves do not escape stereotypes, because every understanding and perception is at least partly based on them. Thus, there is a danger of underestimating the important features of individuals, activities, groups that occur in the context of non-national cultures.

In order to devisualise stereotypical behaviour in practice, the individual in intercultural interaction must be able to: 1) adequately accept and interpret different cultural values; 2) make conscious efforts to overcome barriers to culture and see not only differences but also commonalities with one's own culture in an alien culture; 3 ) look at different cultural phenomena and representatives of other cultures with good faith in order to understand them; 4) be able to compare existing ethno-cultural stereotypes with personal experience and draw independent conclusions; 5) be able to critically evaluate and change their attitude towards alien cultures, accumulate skills and experience of intercultural interaction; 6) strive for a better knowledge of foreign cultures in order to gain a deeper and more critical understanding of one's own, and to overcome the prevailing stereotypes and prejudices; 7) systematise the facts of cultural life; 8) synthesise and summarise own personal experience of intercultural dialogue (Pruskus, 2010, p. 33). 
It is important to remember that all nations and cultures can only flourish if they follow the principle of tolerance. The requirement of tolerance in the context of globalisation is an objective necessity because the world is very diverse and its processes are treated differently by different cultures.

\section{Conclusions}

1. Intercultural business interaction takes place in the medium of different cultures with their inherent features. In their work, world scholars provide various classifications of the types of intercultural business interaction. This paper analyses the classifications of different theoretician cultures in the context of business interaction.

2. In describing the types of intercultural business interaction, it was concluded that Gesteland's classification of cultures is probably the best in reflecting cultural differences of different countries of the world, making it easy to relate their presentation of these differences in the process of intercultural business interaction and negotiation. Gesteland distinguished the classification of intercultural interaction and negotiation types in accordance with the treatment of the main aspects of negotiation (subjectivity, formality, time and emotionality). It allows for a flexible look at the features of intercultural interaction and negotiating in terms of country and region, without only being attached to geographic distribution.

3. It is useful to use the cultural dimensions of Geert Hofstede and his colleagues to analyse the incompatibilities of different cultures. These dimensions also need to be taken into account in pursuit for effective intercultural business and economic interaction, and for productive course of business negotiations.

4. Other scientists' classifications are equally important (Hall, Lewis, Schwartz). The classification of cultures of these scholars, same as those of Gesteland and Geert Hofstede, should be used in the assessment of international business interaction, including negotiation, the constructive communication and negotiating power of participants, and in the development of the international communication strategies. The strategy should provide ways of avoiding the various possible multicultural misunderstandings/incompatibilities.

5. The paper concludes that effective cross-cultural communication in the context of business communication must have elements of creativity. The "approach" to people of different cultures and mentalities should be original, and creative. Creativity is not an exclusive attribute of gifted people, but is achievable by every individual; it is an ability that we must cultivate constantly.

6. The main obstacles to intercultural communication are the inability to master anxiety and uncertainty when communicating with other cultures, the lack of intercultural communication competences, the inability to resolve conflicts arising in intercultural interaction, the lack of appropriate conflict resolution strategies and styles, our own hostile reactions such as the sense of superiority, ethnocentrism, cultural relativity, the premise of universality, stereotypes, etc.

7. These obstacles need to be removed, and this is achieved through the acquisition of knowledge of others, the constant search for information about other cultures, appropriate 
adaptation of communication with others, and development of attentiveness. It is also important to be able to choose the appropriate strategy and style for conflict resolution in intercultural business interaction. No less important is to overcome our individual hostile reactions to other cultures, to be tolerant.

\section{References}

Adler, N. J. (2002). International dimensions of organizational behavior. South-Western College Publishing.

Beebe, S. A., Beebe, S. J., \& Ivy, D. K. (2007). Communication: Principles for a lifetime. Pearson/Allyn \& Bacon.

Casse, P., \& Deol, S. (1985). Managing intercultural negatiations: Guidelines for trainers and negotiators. Sietar International.

Cohen, R. (1991). Negotiating across cultures: Communication obstacles in international diplomacy. United States Institute of Peace Press.

Csikszentmihalyi, M. (1988). Society, culture, and person: A systems view of creativity. In R. J. Sternberg (Ed.), The nature of creativity: Contemporary psychological perspectives (pp. 325-339). Cambridge University Press.

Černevičiūtè, J. ir Strazdas, R. (2014). Kūrybingumo sampratų raida: nuo genijaus ị kūrybines sistemas. Santalka: filosofija, komunikacija, 22(2), 113-125.

Gesteland, R. R. (1997). Kaip išgauti „taip“: menas bendrauti ir derètis įvairiose kultūrose. Tyto alba.

Grakauskaitè-Karkockienė, D. (2002). Kürybos psichologija. Logotipas.

Gudykunst, W. B., \& Kim, Y. Y. (1997). Communication with strangers: An approach to intercultural communication. McGraw-Hill.

Gudonienè, V. (2013). Tarpkultūrinè komunikacija: Mokomoji priemonė. Klaipėda: Socialinių mokslų kolegija.

Hall, E. T. (1983). The dance of life: The other dimension of time. Anchor Books.

Heales, J., Cockcroft, S., \& Raduescu, C. (2004). The influence of national culture on the level and outcome of IS development decisions. Journal of Global Information Technology Management, 7(4), 3-28. https://doi.org/10.1080/1097198X.2004.10856382

Hofstede, G., Hofstede, G. J., \& Minkov, M. (2010). Cultures and organizations: Software of the mind. Intercultural cooperation and its importance for survival. McGraw-Hill.

Jančaitytè, R., Valavičienè, N., Augutienè, R. ir Prakapas, R. (2009). Tarpkultūrinès kompetencijos didinimas bei įvairoves valdymo gebejjimu stiprinimas. Vilnius: Tarptautinès migracijos organizacijos.

Javidan, M. (2004). Performance orientation. In R. J. House, P. J. Hanges, M. Javidan, P. W. Dorfman, \& V. Gupta (Eds.), Culture, leadership, and organizations: The GLOBE study of 62 societies (pp. 239281). Sage Publications.

Jiaquan, X. (2009). On the development of college students' intercultural competency. International Forum of Teaching and Studies, 5(2), 27-31.

Lazauskienè, A. ir Rimienè, V. (2018). Paauglių, išvykstančių ir neišvykstančių pagal tarptautinių moksleivių mainų programą, sprendimų priemimo stilius ir tarpkultūrinis jautrumas, Ugdymo psichologija: Mokslo darbai, 29, 43-60.

Leonavičius, V. (2007). Kultūrinis reliatyvizmas. Iš Visuotiné lietuvių enciklopedija. T. 11. Mokslo ir enciklopedijų leidykla, 231.

Leončikas, T. (2004). Etnocentrizmas. Iš Visuotiné lietuviu enciklopedija. T. 5. Mokslo ir enciklopedijų leidykla, 638. 
Lewis, R. D. (2002). Kultūru sandūra: kaip sèkmingai bendrauti su kitu tautu ir kultūru atstovais. Alma littera.

Lustig, M. W., \& Koester, J. (2006). Intercultural competence: Interpersonal communication across cultures. Pearson.

Mažeikienė, A., \& Peleckis, K. (2011). Verslo derybos. Technika. https://doi.org/10.3846/1196-S

Miller, O. (2014). The negotiation style: A comparative study between the stated and in practice negotiation style. Procedia - Social and Behavioral Sciences, 124, 200-209. https://doi.org/10.1016/j.sbspro.2014.02.478

Nardon, L., \& Steers, R. M. (2009). The culture theory jungle: Divergence and convergence in models of national culture. In R. S. Bhagat \& R. M. Steers (Eds.), Cambridge handbook of culture, organizations, and work (pp. 3-22). Cambridge University Press. https://doi.org/10.1017/CBO9780511581151.002

Partnership for $21^{\text {st }}$ Century Skills. (2008). $21^{\text {st }}$ Century skills, education and competitiveness. http://wieettassessment.pbworks.com/f/21stCenturySkillsEducationandCompetitivenessGuide.pdf

Peleckis, K. (2015). Tarptautinio verslo derybos: tarpasmeniniai konfliktai ir jų valdymo galimybès. Verslo ir teisés aktualijos, 10, 64-82.

Peleckis, K. (2016). Derybiniu galiu vertinimais grindžiamos tarptautinio verslo derybu strategijos (Daktaro disertacija). Technika. https://doi.org/10.20334/2368-M

Peleckis, K., Mažeikienė, A., Peleckienė, V., \& Peleckis, K. (2016). Verslo komunikacija ir derybos. Technika. https://doi.org/10.20334/1556-S

Petkevičiūtè, N. ir Budaitè, R. (2005). Vadovų tarpkultūrinè kompetencija Lietuvos organizacijose. Organizaciju vadyba: sisteminiai tyrimai, 36, 132-149.

Pipirienè, V. ir Maciukevičienè, L. (2011). Komunikacija ir derybos - esminè tarptautinio verslo plètotès prielaida. Verslas: teorija ir praktika, 12(3), 296-302. https://doi.org/10.3846/btp.2011.30

Pruskus, V. (2003). Verslo etika: laiko ǐšūkiai ir atsako galimybès. Enciklopedija.

Pruskus, V. (2004). Multikultūrine komunikacija ir vadyba. Vilniaus teisès ir verslo kolegija.

Pruskus, V. (2010). Stereotipai ir jų devizualizacija tarpkultūrinèje komunikacijoje. Filosofija. Sociologija, 21(1), 29-36.

Pruskus, V. (2012). Tarpkultūriné komunikacija ir vadyba. Technika.

Pruskus, V. (2013). Tarpkultūriniai konfliktai: kilimo priežastys ir kompetencijų vaidmuo. Santalka: filosofija, komunikacija, 21(2), 79-89. https://doi.org/10.3846/cpc.2013.08

Radzevičienè, A. (2004). Studijų užsienyje įtaka studentų tarpkultūrinès kompetencijos ugdymui. In Verslas, vadyba ir studijos, 2003 (pp. 62-67). Technika.

Rakauskaitè, E. D. (2014). Kūrybingumo ugdymas - investicija ị kūrybinę visuomenę. Socialinès technologijos, 4(2), 333-347. https://doi.org/10.13165/ST-14-4-2-07

Schwartz, Sh. H. (2006). A theory of cultural value orientations: Explication and applications. Comparative Sociology, 5(2-3), 137-182. https://doi.org/10.1163/156913306778667357

Scollon, R., Wong Scollon, S., \& Jones, R. H. (2012). Intercultural communication: A discourse approach. John Wiley \& Sons, Inc. https://doi.org/10.1002/9781405198431.wbeal0555

Steenkamp, J.-B. E. M. (2001). The role of national culture in international marketing research. International Marketing Review, 18(1), 30-44. https://doi.org/10.1108/02651330110381970

Trompenaars, F., \& Hampden-Turner, Ch. (2012). Riding the waves of culture: Understanding diversity in global business. McGraw-Hill Education.

Tsang, N. K. F. (2011). Dimensions of Chinese culture values in relation to service provision in hospitality and tourism industry. International Journal of Hospitality Management, 30(3), 670-679. https://doi.org/10.1016/j.ijhm.2010.12.002 


\title{
EFEKTYVI KŪRYBINĖ TARPKULTŪRINE் KOMUNIKACIJA DALYKINIO BENDRAVIMO KONTEKSTE: TEORINIAI IR PRAKTINIAI ASPEKTAI
}

\author{
Justinas BRASLAUSKAS
}

\section{Santrauka}

Nors ịvairūs tarpkultūrinės komunikacijos aspektai nagrinèti skirtingų autorių darbuose, iki šiol pasigendama darbų, nušviečiančių tarpkultūrinę komunikaciją naujame kontekste - nusakant efektyvų tarpkultūrinį dalykinị bendravimą, kultūrų klasifikavimo modelių teorinę analizę ir tarpkultūrinių bendravimo kliūčių ịveikimą, derinant teorines bei praktines įžvalgas. Taip pat pasigendama darbų, kuriuose kūrybiškumas būtų nušviečiamas kaip sudètinè tarpkultūrinès dalykinės komunikacijos dalis. Straipsnio autoriaus ịsitikinimu, be glaudžios šių aspektų sintezès neįmanoma iš esmès suvokti veiksmingos tarpkultūrinès dalykinès komunikacijos prasmès. Straipsnio tikslas - išanalizuoti efektyvaus tarpkultūrinio dalykinio bendravimo, pagrịsto kūrybiškumu, teorinius ir praktinius aspektus. Straipsnyje, pasitelkiant i̇vairių pasaulio mokslininkų (Richardo R. Gestelando, Edwardo T. Hallo, Richardo D. Lewiso, Geerto Hofstede's, Gerto Jano Hofstede's, Michaelo Minkovo, Shalomo H. Schwartzo) kultūrų klasifikavimo modelius, atskleidžiami daugiakultūriškumo tarpkultūrinio dalykinio bendravimo kontekste aspektai. Darbe analizuojamas kūrybiškumas kaip sudètinè efektyvios tarpkultūrinès dalykinès komunikacijos dalis. Publikacijoje taip pat nušviečiamos tarpkultūrinio bendravimo kliūtys ir jų ịveikimo būdai. Darbe taikomi tyrimo metodai: mokslinès literatūros sisteminè, lyginamoji, loginè analizè ir sintezè.

Reikšminiai žodžiai: tarpkultūrinio bendravimo kliūtys, kūrybiškumas, kultūra, tarpkultūrinè komunikacija, daugiakultūriškumas. 